\title{
Hambatan Komunikasi dan Gegar Budaya Warga Korea Selatan Yang Tinggal di Indonesia
}

\author{
Jessica Lestari, Sinta Paramita \\ jessica.915150104@stu.untar.ac.id,sintap@fikom.untar.ac.id
}

Fakultas Ilmu Komunikasi Universitas Tarumanagara

\begin{abstract}
Culture shock will be experienced by someone when going to another country that has cultural differences. This is because every country has a culture that is different from other countries. Besides having cultural differences, the language used by South Korean and Indonesian are different. The purpose of this study was to find out how communication barriers and culture shocked South Korean living in Indonesia. The theories used in this study are theory of communication, culture, intercultural communication, communication barriers and culture shock. The research method used qualitative research of phenomenology descriptively. The conclusion of this study is that communication barriers are one of the reasons of Korean experience a culture shock. Language and cultural differences cause Korean experience a culture shock. Food, transportation, habits, religion and geography also cause Korean experience a culture shock.
\end{abstract}

Keywords: South Korean, Culture Shock, Communication Barriers

\begin{abstract}
Abstrak
Gegar budaya akan dialami seseorang apabila pergi ke negara lain yang memiliki perbedaan budaya. Hal tersebut terjadi karena setiap negara memiliki budaya yang berbeda dengan negara lainnya. Selain memiliki perbedaan budaya, bahasa yang dipakai warga Korea Selatan dan warga Indonesia juga berbeda. Tujuan penelitian ini adalah untuk mengetahui bagaimana hambatan komunikasi dan gegar budaya warga Korea Selatan yang tinggal di Indonesia. Penelitian ini menggunakan teori komunikasi, budaya, komunikasi antarbudaya, hambatan komunikasi, dan gegar budaya. Metode yang digunakan adalah metode penelitian kualitatif fenomenologi secara deskriptif. Penelitian ini menyimpulkan bahwa hambatan komunikasi yakni perbedaan bahasa dan budaya, menjadi salah satu penyebab warga Korea Selatan mengalami gegar budaya. Makanan, transportasi, kebiasaan, agama dan geografi juga menjadi penyebab warga Korea Selatan mengalami gegar budaya.
\end{abstract}

Kata Kunci: warga Korea Selatan, gegar budaya, hambatan komunikasi

\section{Pendahuluan}

Berdasarkan data yang diambil dari Kementerian Luar Negeri, jumlah warga Korea Selatan yang tinggal di Indonesia terus meningkat antara tahun 2013 dan 2016, dari 40.000 orang menjadi 46.000 orang (https://tirto.id/mengapa-semakin-banyakwarga-korsel-belajar-bahasa-indonesia-der2).

Gegar budaya akan dialami seseorang apabila pergi ke negara lain yang memiliki perbedaan budaya. Hal tersebut dikarenakan setiap negara memiliki budaya yang berbeda dengan negara lainnya. Budaya mempengaruhi cara berpikir manusia, cara bertingkah laku serta cara berkomunikasi satu dengan lainnya. Selain memiliki 
perbedaan budaya, bahasa yang dipakai warga Korea Selatan dan warga Indonesia juga berbeda.

Indonesia merupakan negara kepulauan yang memiliki kekayaan, keragaman budaya, ras, suku bangsa, kepercayaan, agama, bahasa daerah, dan lain sebagainya. Banyaknya ragam budaya di Indonesia menyebabkan hambatan bagi warga Korea Selatan.

Berdasarkan latar belakang diatas, rumusan masalah dalam penelitian ini adalah bagaimana hambatan komunikasi dan gegar budaya warga Korea Selatan yang tinggal di Indonesia. Penelitian ini bertujuan untuk mengetahui hambatan komunikasi dan gegar budaya warga Korea Selatan yang tinggal di Indonesia.

\section{Metode Penelitian}

Pada penelitian ini penulis menggunakan pendekatan penelitian kualitatif secara deskriptif. Penelitian kualitatif adalah penelitian yang ditunjukkan untuk memahami fenomena sosial dari perspektif setiap individu (Sukmadinata, 2010). Penulis menggunakan metode tersebut untuk mengetahui fenomena hambatan komunikasi dan gegar budaya yang dialami warga Korea Selatan yang tinggal di Indonesia. Penulis menggunakan metode penelitian kualitatif yang bersifat deskriptif dengan pendekatan fenomenologi. Metode penelitian deskriptif kualitatif ini memungkinkan penulis untuk mengamati secara mendalam mengenai pengalaman warga Korea Selatan yang mengalami hambatan komunikasi dan gegar budaya di Indonesia.

Dalam penelitian ini, penulis memakai beberapa teknik pengumpulan data seperti wawancara, observasi, studi kepustakaan dan penelusuran data online agar dapat mengumpulkan data dan informasi secara mendalam.

Subjek dalam penelitian penulis adalah warga Korea Selatan yang tinggal di Indonesia, yaitu Kim So Hyun, Ryu Jin Yeol dan Choi Hee Chang. Sedangkan objek dalam penelitian penulis adalah hambatan komunikasi dan gegar budaya yang dialami oleh warga Korea Selatan.

Untuk membuktikan keabsahan data, penelitian ini menggunakan teknik triangulasi data dan triangulasi sumber. Trigulasi yaitu teknik pemeriksaan keabsahan data yang memanfaatkan data lain sebagai perbandingan terhadap data (Moleong, 2009).

\section{Hasil Temuan dan Diskusi}

Menurut informan Fahri, hambatan komunikasi adalah susahnya orang asing berkomunikasi dengan orang Indonesia. Seperti banyak orang Indonesia yang bisa bahasa Inggris tetapi tidak banyak orang asing yang bisa bahasa Inggris. Jadi itu salah satu yang membuat komunikasi menjadi terhambat (wawancara dengan Fahri di Jakarta Selatan pada tanggal 29 Mei 2019 pukul 04:10 WIB).

Berdasarkan wawancara dengan Kim So Hyun, ia mempunyai pengalaman terhadap hambatan komunikasi. Hal tersebut dikarenakan saat datang pertama kali ke Indonesia, Kim So Hyun tidak bisa berbahasa Indonesia. Selain itu, bahasa Inggris yang dikuasai Kim So Hyun kurang baik, dan pelafalan bahasa Inggris warga Korea Selatan dengan warga Indonesia sedikit berbeda. Kim So Hyun kesulitan untuk berkomunikasi dengan warga Indonesia saat pertama kali datang ke Indonesia.

Hambatan komunikasi lainnya yang dialami Kim So Hyun adalah saat belajar bahasa Indonesia di BIPA, Kim So Hyun merasa kesulitan dalam memahami pola 
kalimat bahasa Indonesia. Pola kalimat bahasa Indonesia yaitu SPOK (Subjek, Predikat, Objek, Keterangan), sedangkan pola kalimat bahasa Korea kebalikannya. Sebagai contoh, dalam bahasa Indonesia "saya mau makan nasi", sedangkan bahasa Korea "saya nasi makan mau". Selain itu di bahasa Korea tidak ada pelafalan "r", sehingga saat pertama kali Kim So Hyun mendengar pelafalan bahasa Indonesia banyak menggunakan "r", Kim So Hyun merasa asing dan tidak terbiasa. Selain itu, ketika Kim So Hyun belajar di BIPA, Bahasa Indonesia yang dipelajarinya adalah bahasa formal. Tetapi saat berkomunikasi dengan warga Indonesia, mereka menggunakan bahasa informal atau bahasa sehari-hari. Hal tersebut membuat Kim So Hyun kesulitan berkomunikasi (Wawancara dengan Kim So Hyun di Jakarta Pusat pada tanggal 10 Mei 2019 pukul 17:15 WIB).

Menurut Fahri informan dalam penelitian ini, gegar budaya atau culture shock adalah sebagai orang baru di tempat baru yang tidak bisa menyesuaikan keadaan di tempat baru yang kita tinggali tersebut (Wawancara dengan Fahri di Jakarta Selatan pada tanggal 29 Mei 2019 pukul 04:10 WIB).

Berdasarkan wawancara dengan Kim So Hyun, ia terkejut karena di Indonesia banyak angkot dan motor. Di Indonesia kebanyakan menggunakan transportasi motor (ojek). Sedangkan di Korea, motor tidak sebanyak di Indonesia, sehingga Kim So Hyun merasa takut untuk naik motor karena belum terbiasa. Menurut Kim So Hyun, untuk naik kereta di Indonesia juga butuh waktu yang lama untuk menunggu kereta datang dan waktunya tidak tentu. Sedangkan di Korea biasanya serba cepat, kereta di Korea selalu datang terus tanpa menunggu lama. Selain itu, Kim So Hyun merasa kaget setelah melihat warga Indonesia yang makan menggunakan tangan dan di restoran Indonesia disediakan sendok dan garpu. Hal tersebut dikarenakan di Korea Selatan terbiasa makan dengan alat makan seperti sendok dan sumpit. (Wawancara dengan Kim So Hyun di Jakarta Pusat pada tanggal 10 Mei 2019 pukul 17:15 WIB).

Berdasarkan wawancara dengan Choi Hee Chang, ia merasa kaget dan tidak mengerti banyak warga Indonesia yang suka duduk di lantai, seperti tiduran, makan dan duduk di lantai. Selain itu, menurut Choi Hee Chang, di Indonesia mengutamakan agama sedangkan di Korea tidak. Warga Indonesia banyak yang ingin mengetahui agama yang dianut orang lain dan di Indonesia sangat sopan terhadap agama. Selain agama, ketertiban lalu lintas juga menjadi gegar budaya Choi Hee Chang. Menurutnya, untuk menyebrang jalan di Indonesia harus menerima resiko. Walaupun ada lampu merah, kendaraan masih terus lewat. Lalu pengalaman gegar budaya lain yang dialami Choi Hee Chang, saat mengantri ke toilet biasanya di Korea membuat baris. Orang yang mengantri di paling depan masuk saat ada yang keluar dari toilet. Tapi di Indonesia setiap toilet ada satu orang yang menunggu di depan pintu toilet (Wawancara dengan Choi Hee Chang di Puri Indah Mall, Jakarta Barat pada tanggal 18 Mei 2019 pukul 17:50 WIB).

\section{Simpulan}

Warga Korea Selatan tidak menguasai bahasa Indonesia saat pertama kali tinggal di Indonesia. Hambatan komunikasi merupakan salah satu penyebab terjadinya gegar budaya yang dialami warga Korea Selatan yang tinggal di Indonesia. Hal itu disebabkan karena adanya perbedaan bahasa. Selain hambatan komunikasi, gegar budaya yang dialami warga Korea Selatan yang tinggal di Indonesia adalah perbedaan makanan, masalah transportasi, agama, kebiasaan dan faktor geografi. 


\section{Ucapan Terima Kasih}

Penulis mengucapkan terima kasih kepada para narasumber yang telah membantu selama proses pengumpulan data penelitian ini dan kepada seluruh pihak Fakultas Ilmu Komunikasi Universitas Tarumanagara.

\section{Daftar Pustaka}

Agatha, Tashya E., Gregorius Genep Sukendro. (2018). Kreativitas Dan Budaya (Studi Kasus Creative Director Etnis Tionghoa Dalam Industri Peri-klanan). Jurnal Prologia, 2, 2.

https://journal.untar.ac.id/index.php/prologia/article/view/3738/2174

https://tirto.id/mengapa-semakin-banyak-warga-korsel-belajar-bahasa indonesia-der2

Moleong, Lexy J. (2012). Metodelogi Penelitian Kualitatif. Bandung: Remaja Rosdakarya

Setyo Utami, L. (2016). Teori-Teori Adaptasi Antar Budaya. Jurnal Komunikasi, 7(2), 180-197. https://journal.untar.ac.id/index.php/komunikasi/article/view/17/38

Sukmadinata, Nana Syaodih. (2010). Metodelogi Penelitian Pendidikan. Bandung: Remaja Rosdakarya

Tanto Wijaya, Rizky, Suzy S. Azeharie, dan Muhammad Adi Pribadi. (2018).

Fenomena Ciong Pada Budaya Penganut Konghucu. Jurnal Koneksi, 2, 2. https://journal.untar.ac.id/index.php/koneksi/article/view/3934/2317 